\title{
Solanum aethiopicum gr. gilo and Its Interspecific Hybrid with S. melongena as Alternative Rootstocks for Eggplant: Effects on Vigor, Yield, and Fruit Physicochemical Properties of Cultivar 'Scarlatti'
}

\author{
Leo Sabatino ${ }^{1, *}\left(\mathbb{D}\right.$, Giovanni Iapichino ${ }^{1}$, Giuseppe Leonardo Rotino ${ }^{2}\left(\mathbb{0}\right.$, Eristanna Palazzolo ${ }^{1}$, \\ Giuseppe Mennella ${ }^{3}$ (D) and Fabio D'Anna ${ }^{1}$ \\ 1 Dipartimento Scienze Agrarie, Alimentari e Forestali, Università di Palermo, Viale delle Scienze, \\ 90128 Palermo, Italy; giovanni.iapichino@unipa.it (G.I.); eristanna.palazzolo@unipa.it (E.P.); \\ fabio.danna@unipa.it (F.D.) \\ 2 Consiglio per la Ricerca in Agricoltura e l'Analisi dell'Economia Agraria CREA-GB, Centro di Ricerca \\ Genomica e Bioinformatica, Via Paullese, 26836 Montanaso Lombardo (LO), Italy; \\ giuseppeleonardo.rotino@crea.gov.it \\ 3 Consiglio per la Ricerca in Agricoltura e l'Analisi dell'Economia Agraria CREA-OF, Centro di Ricerca \\ Orticoltura e Florovivaismo, Via Cavalleggeri, 84098 Pontecagnano-Faiano, Italy; \\ giuseppe.mennella@crea.gov.it \\ * Correspondence: leo.sabatino@unipa.it; Tel.: +39-329-801-6975
}

Received: 26 February 2019; Accepted: 29 April 2019; Published: 30 April 2019

\begin{abstract}
Grafting is generally considered effective in ameliorating vegetable crop tolerance to biotic and abiotic stresses. The use of interspecific hybrid as rootstock for eggplant may represent a valid alternative approach to enhance eggplant performance. However, studies on the effects of different rootstocks on eggplant plant vigor, yield, and fruit quality traits often show conflicting results. Thus, an experiment was performed in two spring-summer growing seasons (2014 and 2015) by grafting eggplant 'Scarlatti' $\mathrm{F}_{1}$ hybrid on two accessions of S. aethiopicum gr. gilo and on the interspecific hybrid S. melongena $\times$ S. aehtiopicum gr. gilo in comparison to the most common eggplant rootstock S. torvum. Results indicate that $S$. melongena $\times$ S. aethiopicum gr. gilo interspecific hybrid and S. torvum improved grafting success, plant vigor, early flowering and yield in 'Scarlatti' $F_{1}$ scion. All rootstocks tested did not negatively influence fruit apparent quality traits and fruit quality composition. Moreover, fruit glycoalkaloids content remained below the recommended threshold value. These findings suggest that the use of S. melongena $\times$ S. aethiopicum gr. gilo interspecific hybrid as rootstock may be a good alternative to the most commonly used $S$. toroum.
\end{abstract}

Keywords: wild eggplant relative; interspecific hybrid; scion/rootstock combination; plant vigour; yield; fruit quality attributes

\section{Introduction}

Eggplant (Solanum melongena L.) is the world's sixth most important vegetable after tomato, watermelon, onion, cabbage, and cucumber [1] and the most important Solanum crop native to the Old World [2]. Sicily is one of the most important production areas within the Mediterranean Basin that is considered a secondary center of diversification [3]. Soilborne diseases arising from continuous cropping are major problems that limit productivity in eggplant [4]. Therefore, improving soilborne resistance is one of the major scientific and economic challenges in eggplant. Grafting has been attempted as an effective mean to control soilborne diseases and abiotic stresses while simultaneously 
not adversely affect plant growth or even to improve vigor and yield [4]. Among the abiotic stresses that affect vegetable crops, salinity continues to be a main factor in reducing vegetable crop yield and profits in many arid and semi-arid regions. In this respect, Colla et al. [5] demonstrated the effectiveness of grafting to improve salinity tolerance in cucumber. However, the use of specific rootstocks may offer many other advantages such as drought resistance [6] or heavy metal tolerance [7].

Solanum torvum $\mathrm{Sw}$. is the rootstock commonly used for grafting, especially in the most intensive protected cultivation. However, its use has been limited due to lack of rapid and homogeneous synchronized seed germination [8]. Studies have shown that grafting can affect yield and fruit quality in eggplant [9,10]. Kyriacou et al. [11], in their review, reassessed that grafting itself and the prevalence of particular type of commercial rootstocks influence vegetable fruit quality and, partially, storability. They also reported that grafting significantly affects morphometric traits, textural characteristics, sweetness and acidity, as well as functional compounds in eggplant. However, according to Kyriacou et al. [11], current reports on the changes conferred by grafting on eggplant fruit quality provide conflicting information probably due to the environment in which experiment were run. In particular, they stressed both possible rootstock-scion interactions, underscoring graft combinations and different stemming from failure to standardize fruit harvest maturity. In this respect, Gisbert et al. [9] and Sabatino et al. [10] found that the use of interspecific hybrid rootstocks derived from compatible crosses of eggplant with related species can be a valuable approach to improve/preserve eggplant production.

Solanum aethiopicum gr. gilo (scarlet eggplant), a close relative species of S. melongena, has been considered a noticeable resource for eggplant genetic improvement and as potential rootstock. It presents traits of interest, including resistance to F. oxysporum f. sp. melongenae, R. solanacearum [12,13], and root-knot nematodes [14]. Since scarlet eggplant is a cultivated species, it does not display those undesirable traits that are commonly present in the wild relatives of eggplant such as small fruit production, presence of prickles, and high saponins and glycoalcaloids concentrations [15]. A great genetic and morphological variability has been evidenced in S. aethiopicum [16]; therefore, it is particularly relevant to characterize the accessions for the presence and expressivity of the traits of interest before starting a breeding program. Interspecific sexual and somatic hybrids between S. melongena and S. aethiopicum gr. gilo have been produced and although they present a high degree of sterility, recombination between the two genomes has been demonstrated [17] and backcross generations to S. melongena with useful introgressions of S. aethiopicum gr. gilo obtained $[13,18,19]$. The aim of this work was to explore the possibility to use two accessions of S. aethiopicum gr. gilo and an initial highly fertile introgression line $\left(\mathrm{BC}_{1}\right)$ from the somatic hybrid between $S$. melongena and $S$. aethiopicum gr. gilo as rootstock for eggplant. The introgression line was resistant to Fusarium oxysporum f.sp. melongenae and is the founder of the series of improved eggplant lines resistant to Fusarium wilt carrying the resistant locus RfoSa1 [18]. The effects of these three genetic materials when used as rootstock, on vigor, yield, and fruit quality traits of eggplant 'Scarlatti' $\mathrm{F}_{1}$ hybrid were evaluated. The results are compared with those obtained from ungrafted, self-grafted, and S. torvum rootstock grafted plants. Therefore, our aim was also to validate the assumption that using interspecific hybrid rootstocks may be a good approach to enhance eggplant performance because the presence of the eggplant genome together that one of the wild/allied species may improve the overall affinity between rootstock and scion exploiting the advantage of grafting.

\section{Materials and Methods}

\subsection{Plant Material}

The eggplant $\mathrm{F}_{1}$ hybrid 'Scarlatti' (black cylindrical shape) (EnzaZaden, The Netherlands) was used as the scion cultivar as well as the rootstock and ungrafted control. Five rootstocks were evaluated, which included materials corresponding to the three species $S$. melongena $\left(\mathrm{F}_{1}\right.$ hybrid 'Scarlatti'), Solanum torvum, and Solanum aethiopicum gr. gilo (two accessions, named accession 1 and accession 2), and one interspecific hybrid of $S$. melongena $\times$ S. aethiopicum gr. gilo, which is a double haploid line 
obtained from another culture of the tetraploid backcrosses from the somatic hybrid eggplant $\mathrm{cv}$ Dourga(+) S. aethiopicum gr. gilo accession 2 with a tetraploid plant of the eggplant line DR2 [13,18]. The materials used as rootstocks originated from the germplasm collection of the Consiglio per la Ricerca in Agricoltura e l'Analisi dell'Economia Agraria CREA-GB, Centro di Ricerca Genomica e Bioinformatica (Montanaso Lombardo, Italy).

\subsection{Seedlings Production and Grafting}

For the production of the grafted plant material, on 10 February 2014 and 9 February 2015, S. aethiopicum gr. gilo and S. torvum rootstock seeds were planted in 40-cell seedling trays (cell volume of $83 \mathrm{~cm}^{3}$ ), under a temperature regime of $25^{\circ} \mathrm{C} / 18^{\circ} \mathrm{C}$ (day/night) in a propagation greenhouse. After 20 days, seeds of the $F_{1}$ 'Scarlatti' eggplant were planted in 104-cell trays (cell volume of $33 \mathrm{~cm}^{3}$ ) under the same temperature regime and planting method as the rootstocks. Due to the faster germination and growth, the $S$. melongena $\times$ S. aethiopicum gr. gilo hybrid rootstock was sown simultaneously to the $F_{1}$ 'Scarlatti' hybrid. Trays were watered manually every day to maintain the substrate at water holding capacity. Seventy-five days after the sowing of S. torvum and S. aethiopicum gr. gilo (accessions 1 and 2), all seedlings had reached an adequate diameter for grafting. The eggplant cultivar Scarlatti was grafted onto 'Scarlatti' rootstocks (self-grafted), S. torvum, S. aethiopicum gr. gilo (accession 1 and accession 2 ), and S. melongena $\times$ S. aethiopicum gr. gilo rootstocks using the tube grafting method described by Lee [20] and modified by Miceli et al. [21]. Plants at the 3-4 leaf stage were used as rootstocks. The grafted plantlets were misted, incubated within a plastic tunnel in a greenhouse, and maintained at a temperature of $20^{\circ} \mathrm{C}$ and a humidity rate of $95 \%$ for 7 days. After 7 days, the grafted plantlets were acclimatized to the natural conditions of the greenhouse by slowly dropping the humidity ( $\mathrm{RH} 70-80 \%$ ) for 3 days, until they were ready for transplant.

\subsection{Cultivation Conditions}

'Scarlatti' plants ungrafted, self-grafted, and grafted onto S. melongena, S. torvum, and accession 1 and 2 of S. aethiopicum gr. gilo rootstocks were transplanted on 5 May 2014 and 4 May 2015 on a Typic Rhodoxeralf soil in the experimental farm of the Department of Agricultural, Alimentary and Forest Sciences (SAAF) (longitude 13 $19^{\prime} \mathrm{E}$, latitude $38^{\circ} 09^{\prime} \mathrm{N}$ ), of the University of Palermo, Italy. The field trials were conducted in a sandy clay loam soil (46.5\% sand, $22.3 \%$ silt, 31.2 clay) at pH 7.2 in a completely randomized design with 4 replications of 10 plants ( 40 plants per treatment). In both years, the preceding crop was cauliflower. Plants were spaced $1.0 \mathrm{~m}$ between rows and $0.5 \mathrm{~m}$ apart within the row and drip irrigated. Fertilization was applied with drip irrigation throughout the growing cycle and consisted of $250 \mathrm{~kg}$ nitrogen ha ${ }^{-1}, 150 \mathrm{~kg}$ phosphorous pentoxide ha ${ }^{-1}$, and $250 \mathrm{~kg}$ potassium oxide ha ${ }^{-1}$ (Yara, Oslo, Norway). Standard horticultural practices for eggplant production in the Mediterranean environment were adopted [22].

Average daily temperature during the experimental period from May to August of 2014 and 2015 was obtained from the meteorological station of the experimental farm of the Department SAAF (Figure S1). In terms of temperatures, the weather during the experimental period in 2014 and 2015 was similar to the long term average. Nevertheless, the average monthly temperatures showed the highest negative deviation in June (1.8 and $2.2^{\circ} \mathrm{C}$ in 2014 and 2015, respectively).

\subsection{Grafting Success, Biometric Parameters, Yield, and Apparent Fruit Quality Evaluation}

Grafting success was recorded after two weeks from grafting and was calculated on 100 grafted seedlings for each rootstock used. Plant height and root collar diameter (via a digital caliper) at 50, 80 , and 110 days after transplanting (DAT), number of leaves at $50 \mathrm{DAT}$, and aboveground biomass produced at the end of fruit harvest (including total yield and vegetative part produced (weight of the plant at the end of harvests plus vegetative part removed by pruning after plant branching)) were determined. First flower formation (expressed as DAT) were also recorded. 
Immediately after harvesting fruits were weighed. Total yield $\left(\mathrm{kg} \mathrm{plant}^{-1}\right)$, marketable yield $(\mathrm{kg}$ plant $\left.^{-1}\right)$, and number of marketable fruits per plant were collected. Average marketable fruit weight (g) was calculated.

Color ( $\mathrm{a}^{*}$ and $\mathrm{b}^{*}$ parameters -CIELab) was measured on four replications of five fruits per rootstock-scion combination. The records were taken on two opposite point of eggplant fruit skin (equatorial zone) by a colorimeter (Chroma-meter CR-400, Minolta Corporation, Ltd., Osaka, Japan). Hue angle $\left(\mathrm{H}^{\circ}\right)$ was calculated as follows: $\mathrm{H}^{\circ}=\arctan \left(\mathrm{b}^{*} / \mathrm{a}^{*}\right)$.

Fruit firmness was determined by measuring its resistance to the plunger of a digital penetrometer (Trsnc, Italy). Each fruit was subjected to a compression in two opposite point in the equatorial part using a $6 \mathrm{~mm}$ diameter stainless steel cylinder probe. The mean peak force was calculated in Newton $(\mathrm{N})$.

Apparent fruit quality traits of 'Scarlatti' eggplant fruit were measured in four replications of ten representative commercially mature fruits from non-grafted and self-grafted plants, and from plants derived from 'Scarlatti' scions grafted onto S. torvum and accession 1 and 2 of S. aethiopicum gr. gilo hybrid rootstocks. Fruit length/width ratios were calculated. Several traits were measured in an arbitrary scale according to the European Eggplant Genetic Resources Network (EGGNET) descriptors [23]. These traits included fruit curvature $(1=$ none; $9=\mathrm{U}$-shaped $)$, fruit cross section $(1=$ circular; $9=$ very irregular), fruit calyx length $(1=$ very short $(>10 \%) ; 9=$ very long $(>75 \%))$, and fruit calyx prickles $(0=$ none; $9=$ very many $(>30))$. In addition to these EGGNET descriptors, seed index $(0=$ none; $5=$ very many $(>80)$ seeds visible in a longitudinal fruit section $)$ was measured.

\subsection{Pulp Browning, Soluble Solid Content, and Chemicals}

The colorimeter was also used to determine the lightness of fruit pulp by measuring $L^{*}$ value $(0=$ black and $100=$ white). Fruits were sectioned in the equatorial part and the color of the pulp was measured immediately after cutting $\left(\mathrm{L}_{0}\right)$ and after $30 \mathrm{~min}\left(\mathrm{~L}_{30}\right)$ in two areas (central and lateral) of the section. The oxidation potential was estimated using Larrigaudiere et al. [24] method with little modifications as in part suggested by Concellòn et al. [25]. The oxidation potential was expressed as $\Delta \mathrm{L}_{30}=\left(\mathrm{L}_{30}-\mathrm{L}_{0}\right)$.

Sampling for the quality analysis of the fruits was carried out as described by Sabatino et al. [10] and Sabatino et al. [26]. Thus, 3-5 commercially mature fruits for each replication from the second and third harvest were used; only healthy fruits were chosen. Care was taken to ensure that each sample contained the same percentage weight of apical, middle, and distal parts of the fruits. Qualitative fruit characteristic analyses were conducted on fruits harvested from labeled fruits (the flowers were labeled at the fruit set stage) and all fruits were harvested after 35 days from labeling (fruit commercial maturity stage).

Sample of the fruit pulp were squeezed by hand with a garlic squeezer. The juice was filtered and soluble solids content (SSC) was measured using a digital refractometer (MTD-045nD, Three-In-One Enterprises Co. Ltd. Taiwan).

Fruit dry matter percentage was determined in samples dried at $105^{\circ} \mathrm{C}$ until constant weight as $100 \% \times($ dry weight/fresh weight).

Proteins, metals, total anthocyanins, chlorogenic acid, and glycoalkaloids were determined only in the second trial (2015). Protein concentration was determined from $\mathrm{N}$ content obtained from the Kjeldahl method. In particular, a sample rate was subjected to acid-catalyzed mineralization to turn the organic nitrogen into ammoniacal nitrogen. The ammoniacal nitrogen was then distilled in an alkaline $\mathrm{pH}$. The ammonia formed during this distillation was collected in a boric acid solution and determined through titrimetric dosage. The protein concentration was reported as $\mathrm{N} \times 6.25$. Phosphorus content were assessed using colorimetry [27]. $\mathrm{Ca}, \mathrm{Mg}$, and $\mathrm{K}$ were determined using atomic absorption spectroscopy following wet mineralization [28].

Polyphenols were extracted and analyzed according to Stommel and Whitaker [29] with minor modifications. The analyses were performed through a Waters E-Alliance HPLC system constituted 
by a 2695 separations module with quaternary pump, auto sampler, and a 2996 photodiode array detector; data were acquired and analyzed with Waters Empower software on a personal computer. A binary mobile phase gradient of methanol in $0.01 \%$ aqueous phosphoric acid was used according to this procedure: $0-15 \mathrm{~min}$, linear increase from 5 to $25 \%$ methanol; $15-28 \mathrm{~min}$, linear increase from 25 to $50 \%$ methanol; $28-30 \mathrm{~min}$, linear increase from 50 to $100 \%$ methanol; $30-32 \mathrm{~min}, 100 \%$ methanol; 32-36 $\mathrm{min}$, linear decrease from 100 to $5 \%$ methanol; $36-43 \mathrm{~min}, 5 \%$ methanol. The flow rate was $0.8 \mathrm{~mL} / \mathrm{min}$. Quantification of chlorogenic acid (CA), carried out after a RP-HPLC separation, was based on absorbance at $325 \mathrm{~nm}$ relative to the sesamol internal standard and an external standard of authentic CA (Sigma-Aldrich, St. Louis, MO). The results were expressed as $\mathrm{mg} \cdot 100 \mathrm{~g}^{-1} \mathrm{of} \mathrm{fw}$.

The extraction and the analysis of anthocyanins were carried out on $200 \mathrm{mg}$ of lyophilized and powdered peel as reported in Mennella et al. [30]. Briefly, the chromatographic separations were performed at a flow rate of $0.8 \mathrm{~mL} / \mathrm{min}$ and at 0.1 absorbance units full scale (AUFS). Purified delphinidin-3-rutinoside (D3R, Polyphenols Laboratories AS, Sandnes, Norway) was used as external standard in RP-HPLC analyses, with a different retention time (23.9 $\mathrm{min}$ ) compared to delphinidin-3-(p-coumaroylrutinoside)-5-glucoside (nasunin), that was eluted at a longer retention time (25.8 min for cis-nasunin and $26.1 \mathrm{~min}$ for trans-nasunin, respectively). As for nasunin quantification, a partially purified standard was used according to Lo Scalzo et al. [31]. The results were expressed as $\mathrm{mg} \cdot 100 \mathrm{~g}^{-1}$ of peel $\mathrm{fw}$; the limit of detection was $2.00 \mathrm{mg} \cdot 100 \mathrm{~g}^{-1}$ of peel $\mathrm{dw}$.

Glycoalkaloids were extracted as described by Birner [32] with some modifications. Glycoalkaloid extraction was detected from $0.5 \mathrm{~g}$ lyophilized samples and powdered flesh tissue by $95 \%$ ethanol. The analyses were carried out by means of RP-HPLC according to Kuronen et al. [33] using partially purified solasonine and solamargine as the external standard. The data were expressed as $\mathrm{mg} \cdot 100 \mathrm{~g}^{-1}$ $\mathrm{fw}$; the limit of detection was $0.03 \mathrm{mg} \cdot 100 \mathrm{~g}^{-1} \mathrm{of} \mathrm{dw}$.

\subsection{Statistical Analysis}

Data were statistically analyzed by a two-way analysis of variance (ANOVA) (year $(\mathrm{Y}) \times$ rootstock (R)) using SPSS software package version 14.0 (StatSoft, Inc., Chicago, IL, USA). Proteins, metals, total anthocyanins, chlorogenic acid and glycoalkaloids, which were determined only in the second trial (2015), were analyzed via one-factor analysis of variance (ANOVA) using a fixed-effects model for the effect of rootstock treatment. For data expressed in percentage, the arcsin transformation before ANOVA analysis $\left[\varnothing=\arcsin (\mathrm{p} / 100)^{1 / 2}\right]$ was applied. To separate treatment means within each measured parameter, Tukey HSD test was performed at $p=0.05$.

\section{Results}

The interaction between rootstock and year was always not significant; therefore, for the sake of simplicity it was omitted from the tables and graphs. Similarly, the factor year was statistically significant only for first flower formation and is reported only in the correspondent table.

\subsection{Grafting Success and Plant Biometric Parameters}

Rootstock significantly affected grafting success, number of leaves at 50 DAT and aboveground biomass (Table 1). 
Table 1. Year and rootstock effects on grafting success and plant biometric parameters of 'Scarlatti' $\mathrm{F}_{1}$ scion.

\begin{tabular}{|c|c|c|c|c|}
\hline Treatments & $\begin{array}{c}\text { Grafting } \\
\text { Success (\%) }\end{array}$ & $\begin{array}{l}\text { No. Leaves } 50 \\
\text { DAT (No.) }\end{array}$ & $\begin{array}{l}\text { Aboveground } \\
\text { Biomass (kg) }\end{array}$ & $\begin{array}{c}\text { First Flower } \\
\text { Formation (DAT) }\end{array}$ \\
\hline \multicolumn{5}{|l|}{ Rootstock } \\
\hline 'Scarlatti' ungrafted & - & $17.5 \mathrm{~b}$ & $4.5 \mathrm{ab}$ & $53.1 \mathrm{a}$ \\
\hline S. torvum & $99.3 \mathrm{a}$ & $24.3 \mathrm{ab}$ & $5.1 \mathrm{a}$ & $49.0 \mathrm{~d}$ \\
\hline 'Scarlatti' self-grafted & $99.6 \mathrm{a}$ & $25.4 \mathrm{a}$ & $4.9 \mathrm{a}$ & $52.9 \mathrm{ab}$ \\
\hline $\begin{array}{l}\text { Hybrid S. melongena } \times \\
\text { S. aethiopicum }\end{array}$ & $99.0 \mathrm{a}$ & $21.1 \mathrm{ab}$ & $4.6 \mathrm{ab}$ & $49.3 \mathrm{~d}$ \\
\hline S. aethiopicum (accession 1) & $93.6 \mathrm{~b}$ & $27.3 \mathrm{a}$ & $3.7 \mathrm{c}$ & $51.9 \mathrm{bc}$ \\
\hline S. aethiopicum (accession 2) & $89.1 \mathrm{~b}$ & $17.6 \mathrm{~b}$ & $4.0 \mathrm{bc}$ & $51.5 \mathrm{c}$ \\
\hline \multicolumn{5}{|l|}{ Year } \\
\hline 2014 & $96.5 \mathrm{a}$ & $22.3 \mathrm{a}$ & $4.4 \mathrm{a}$ & $52.0 \mathrm{a}$ \\
\hline 2015 & $95.8 \mathrm{a}$ & $22.1 \mathrm{a}$ & $4.5 \mathrm{a}$ & $50.6 \mathrm{~b}$ \\
\hline \multicolumn{5}{|l|}{ Significance } \\
\hline Rootstock & $* * *$ & $* *$ & $* * *$ & $* * *$ \\
\hline Year & NS & NS & NS & $* * *$ \\
\hline
\end{tabular}

DAT, days after transplanting. Values within a column and a year followed by the same letter are not significantly different at $p \leq 0.05$ (Tukey HSD Test). The significance is designated by asterisks as follows: ${ }^{*}$, statistically significant differences at $p$-value below $0.05 ;{ }^{* *}$, statistically significant differences at p-value below $0.01 ;{ }^{* * *}$, statistically significant differences at $p$-value below $0.001 ; \mathrm{NS}=$ not significant.

The tube grafting method proved highly efficient with success percentages that ranged from 89.1 to $99.6 \%$ among the materials used (Table 1). No significant differences were found in terms of success rate among 'Scarlatti', S. torvum, and S. melongena $\times$ S. aethiopicum gr. gilo hybrid rootstocks, which showed percentages of graft success ranging from $99 \%$ (S. melongena $\times$ S. aethiopicum gr. gilo hybrid) to $99.6 \%$ ('Scarlatti'). In contrast, S. aethiopicum gr. gilo (accessions 1 and 2) had a significantly lower percentage of success (93.6 and 89.1\%, respectively) with respect to the other rootstocks (Table 1). No visible disaffinity signals at the grafting zone were observed for any rootstock-scion combination.

The mean number of leaves at 50 DAT varied between 17.5 and 27.3 leaves per plant for the 'Scarlatti' ungrafted and S. aethiopicum gr. gilo (accession 1) rootstock, respectively (Table 1). 'Scarlatti' scions grafted onto S. melongena ('Scarlatti') and S. aethiopicum gr. gilo (accession 1) rootstocks had a higher number of leaves at 50 DAT than those ungrafted or grafted onto S. aethiopicum gr. gilo (accession 2). However, eggplant plants grafted onto S. torvum and S. melongena $\times$ S. aethiopicum gr. gilo hybrid did not significantly differ from those grafted onto the other rootstocks tested.

Aboveground biomass produced ranged from $5.1 \mathrm{~kg}$ for 'Scarlatti' grafted on S. torvum rootstock to $3.7 \mathrm{~kg}$ for those grafted on S. aethiopicum gr. gilo (accession 1) rootstock (Table 1). Plants grafted onto S. torvum rootstock did not significantly differ compared to those grafted onto S. melongena (self-grafted plants), whereas the lowest aboveground biomass values were collected from eggplant plants grafted onto S. aethiopicum gr. gilo (accessions 1 and 2) (3.7 and $4.0 \mathrm{~kg}$ ).

Regardless of the rootstock, the second trial (2015) gave the shortest time of first flower formation (50.6 DAT), whereas, irrespective of the year, plants grafted onto S. melongena $\times$ S. aethiopicum gr. gilo hybrid and $S$. torvum gave the shortest time of first flower formation (49.3 and 49.0 DAT, respectively). 'Scarlatti' ungrafted had the longest first flower formation (53.1 DAT) (Table 1).

Rootstock significantly influenced plant height at 50, 80, and 110 DAT (Figure 1).

Plants grafted onto S. aethiopicum gr. gilo (accession 1) had the highest plant height, whereas plants grafted onto S. aethiopicum gr. gilo (accession 2) had the lowest values (Figure S2).

At 80 DAT, no significant differences were found in plant height among 'Scarlatti', S. torvum, S. aethiopicum gr. gilo (accession 1), and S. melongena $\times$ S. aethiopicum gr. gilo hybrid rootstocks. S. aethiopicum gr. gilo (accession 2 ) had a significantly lower plant height value with respect to the other rootstocks (Figure 1). However, plant height at 50 and 110 DAT, in 'Scarlatti' F1 grafted onto 
S. melongena $\times$ S. aethiopicum gr. gilo hybrid rootstocks did not significantly differ from those grafted onto S. aethiopicum gr. gilo (accession 2).

Rootstock significantly influenced root collar at 50, 80, and 110 DAT (Figure S3). Plants grafted onto S. aethiopicum gr. gilo (accession 2) and S. melongena $\times$ S. aethiopicum gr. gilo hybrid rootstocks had the lowest root collar values, whereas plants grafted on S. aethiopicum gr. gilo (accession 1 ) had the highest value (Figure S3).

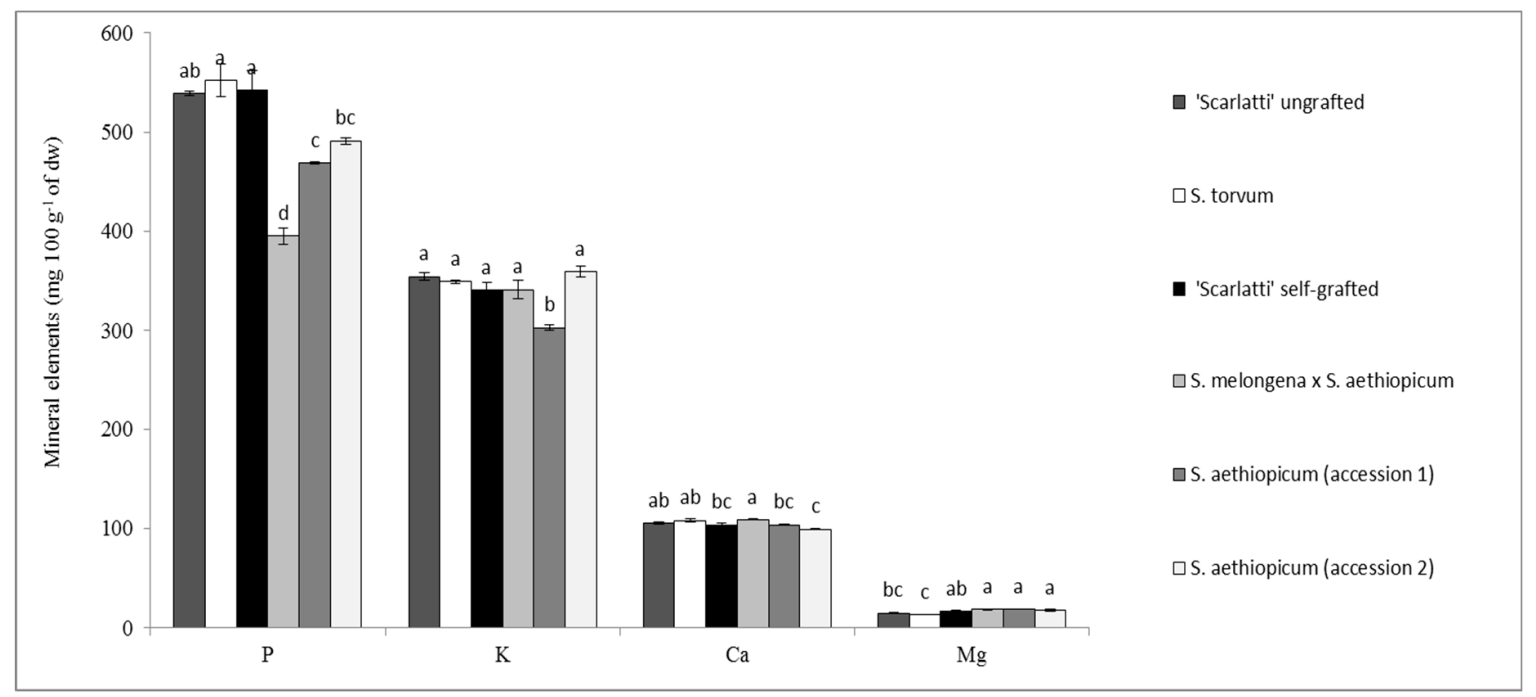

Figure 1. Mineral elements of 'Scarlatti' eggplant fruits produced from ungrafted, self-grafted, and grafted onto S. torvum, S. aethiopicum gr. gilo (accession 1), S. aethiopicum gr. gilo (accession 2), and S. melongena $\times S$. aethiopicum gr. gilo rootstocks. Bars with different letters are significant by Tukey HSD Test $(p<0.05)$.

\subsection{Yield}

Rootstock significantly influenced total yield, marketable yield and number of marketable fruits (Table 2).

Table 2. Rootstock effects on yield traits of 'Scarlatti' $F_{1}$ scion.

\begin{tabular}{|c|c|c|c|c|}
\hline Treatments & $\begin{array}{c}\text { Total Yield } \\
\text { Plant }^{-1}(\mathrm{~kg})\end{array}$ & $\begin{array}{l}\text { Marketable Yield } \\
\text { Plant }^{-1}(\mathrm{~kg})\end{array}$ & $\begin{array}{l}\text { No. Marketable } \\
\text { Fruits Plant }^{-1} \text { (No.) }\end{array}$ & $\begin{array}{c}\text { Average Fruit } \\
\text { Weight (g) }\end{array}$ \\
\hline \multicolumn{5}{|l|}{ Rootstock } \\
\hline 'Scarlatti' ungrafted & $3.4 \mathrm{ab}$ & $3.3 \mathrm{ab}$ & $14.5 \mathrm{a}$ & $231.3 \mathrm{~ns}$ \\
\hline S. torvum & $3.8 \mathrm{a}$ & $3.6 \mathrm{a}$ & $16.6 \mathrm{a}$ & $216.8 \mathrm{~ns}$ \\
\hline 'Scarlatti' self-grafted & $3.9 \mathrm{a}$ & $3.6 \mathrm{a}$ & $16.2 \mathrm{a}$ & $223.5 \mathrm{~ns}$ \\
\hline $\begin{array}{c}\text { Hybrid S. melongena } \times \\
\text { S. aethiopicum }\end{array}$ & $3.4 \mathrm{ab}$ & $3.2 \mathrm{ab}$ & $15.1 \mathrm{a}$ & $213.9 \mathrm{~ns}$ \\
\hline S. aethiopicum (accession 1) & $2.7 \mathrm{c}$ & $2.5 \mathrm{c}$ & $9.1 \mathrm{~b}$ & $330.1 \mathrm{~ns}$ \\
\hline S. aethiopicum (accession 2) & $3.1 \mathrm{bc}$ & $2.9 \mathrm{bc}$ & $14.1 \mathrm{a}$ & $207.5 \mathrm{~ns}$ \\
\hline \multicolumn{5}{|l|}{ Significance } \\
\hline Rootstock & $* * *$ & $* *$ & $* * *$ & NS \\
\hline
\end{tabular}

Values within a column and a year followed by the same letter are not significantly different at $p \leq 0.05$ (Tukey HSD Test). The significance is designated by asterisks as follows: ${ }^{*}$, statistically significant differences at $p$-value below $0.05 ; * *$, statistically significant differences at $p$-value below $0.01 ; * * *$, statistically significant differences at $p$-value below 0.001; NS = not significant.

Total yield ranged between $2.7 \mathrm{~kg} \mathrm{plant}^{-1}$ for 'Scarlatti' grafted on S. aethiopicum gr. gilo (accession 1) and $3.9 \mathrm{~kg}$ plant $^{-1}$ for those grafted onto S. melongena (self-grafted plants) (Table 2). No significant differences were found in the total yield among 'Scarlatti' and S. torvum rootstocks, which had total yield that ranged from $3.8 \mathrm{~kg}$ plant $^{-1}$ (S. torvum) to $3.9 \mathrm{~kg} \mathrm{plant}^{-1}$ ('Scarlatti' self-grafted). S. aethiopicum 
gr. gilo (accessions 1 and 2) had a significantly lower total yield (2.7 and $3.1 \mathrm{~kg} \mathrm{plant}^{-1}$, respectively) than the other rootstocks (Table 2). However, plants grafted onto S. melongena $\times$ S. aethiopicum gr. gilo rootstock and 'Scarlatti' ungrafted plants did not significantly differ in total yield compared to the plants grafted onto 'Scarlatti' and S. torvum rootstocks. Data collected on marketable yield supported the trend established for total yield (Table 2). Plants with S. aethiopicum gr. gilo (accession 1) as rootstock had a significantly lower fruit number in comparison to those grafted onto 'Scarlatti', S. torvum, and S. melongena $\times$ S. aethiopicum gr. gilo hybrid, and not different from those grafted onto S. aethiopicum gr. gilo (accession 2) (Table 2). In addition, no differences were found among plants grafted onto 'Scarlatti', S. torvum, S. melongena $\times$ S. aethiopicum gr. gilo hybrid, and S. aethiopicum gr. gilo (accession 2 ) for number of marketable fruits plant ${ }^{-1}$ which produced a significantly higher number of fruits than accession 1 of S. aethiopicum gr. gilo. No significant differences among treatments were found for the average fruit weight (Table 2).

\subsection{Apparent Fruit Quality}

Rootstock significantly influenced fruit length and fruit calyx length parameters (Table S1). Fruit from plants grafted on $S$. melongena $\times$ S. aethiopicum gr. gilo hybrid rootstock were significantly more elongated than those from plants grafted onto 'Scarlatti' rootstock or from ungrafted 'Scarlatti' plants (Table S1), which in turn had more elongated fruits than those from plants grafted onto S. aethiopicum gr. gilo (accession 2).

Fruit calyx length in 'Scarlatti' scion grafted onto S. aethiopicum gr. gilo $\times$ S. melongena hybrid rootstock was significantly higher than in plants grafted onto $S$. torvum; however, fruits from self-grafted and ungrafted 'Scarlatti' plants did not significantly differ neither from fruits from plants grafted onto S. melongena $\times$ S. aethiopicum gr. gilo hybrid nor from those from plants grafted onto S. torvum. No significant differences among rootstocks tested were found for fruit width (average of $4.7 \mathrm{~cm}$ ), fruit length-width ratio (average of 3.9), fruit curvature (average of 1.0), fruit cross-section (average of 7.1), fruit calyx prickles (average of 0.2 ), or seeds index (average of 1.1) (Table S1).

\subsection{Intrinsic and Extrinsic Fruit Quality}

Hue color parameter in fruits from plants grafted onto S.torvum and S. aethiopicum gr. gilo (accession 1) had the highest values (360.3 and 360.2, respectively) (Table 3).

Table 3. Rootstock effects on Hue ${ }^{\circ}$, fruit dry matter, firmness, and soluble solids content (SSC) in 'Scarlatti' $F_{1}$ scion.

\begin{tabular}{ccccc}
\hline Treatments & $\mathbf{H}^{\circ}$ & Fruit Dry Matter (\%) & Firmness (N) & SSC $\left({ }^{\circ}\right.$ Brix) \\
\hline Rootstock & & & & \\
Scarlatti' ungrafted & $360.1 \mathrm{~b}$ & $7.3 \mathrm{~ns}$ & $60.0 \mathrm{~ns}$ & $4.5 \mathrm{~b}$ \\
S. torvum & $360.3 \mathrm{a}$ & $7.2 \mathrm{~ns}$ & $43.2 \mathrm{~ns}$ & $3.9 \mathrm{c}$ \\
Scarlatti' self-grafted & $360.1 \mathrm{~b}$ & $6.8 \mathrm{~ns}$ & $44.2 \mathrm{~ns}$ & $4.1 \mathrm{c}$ \\
Hybrid S. melongena & $360.0 \mathrm{~b}$ & $6.8 \mathrm{~ns}$ & $49.0 \mathrm{~ns}$ & $4.6 \mathrm{ab}$ \\
S. aethiopicum & $360.2 \mathrm{ab}$ & $6.9 \mathrm{~ns}$ & $50.6 \mathrm{~ns}$ & $4.6 \mathrm{ab}$ \\
S. aethiopicum (accession 1) & $360.1 \mathrm{~b}$ & $6.8 \mathrm{~ns}$ & $38.8 \mathrm{~ns}$ & $4.9 \mathrm{a}$ \\
S. aethiopicum (accession 2) & \multirow{2}{*}{ Significance } & $\mathrm{NS}$ & $\mathrm{NS}$ & $* * *$ \\
Rootstock & \multirow{2}{*}{. } & &
\end{tabular}

Values within a column and a year followed by the same letter are not significantly different at $p \leq 0.05$ (Tukey HSD Test). The significance is designated by asterisks as follows: ${ }^{*}$, statistically significant differences at $p$-value below $0.05 ; * *$, statistically significant differences at p-value below $0.01 ; * * *$, statistically significant differences at $p$-value below 0.001; NS = not significant.

Treatments tested had no effects on fruit dry matter and firmness (Table 3).

Rootstock significantly influenced SSC (Table 3). The highest value of SSC (4.6, 4.9 and $4.6^{\circ} \mathrm{Brix}$, respectively) were found in plants grafted onto S. aethiopicum gr. gilo (accessions 1 and 2) and $S$. 
melongena $\times$ S. aethiopicum gr. gilo hybrid, whereas the lowest value (3.9 and $4.1^{\circ}$ Brix, respectively) were observed in plants grafted onto S. torvum and 'Scarlatti'(Table 3).

'Scarlatti' scions grafted onto S. aethiopicum gr. gilo (accession 1) and S. melongena $\times$ S. aethiopicum gr. gilo, had the highest values of $\mathrm{L}_{0}$ central area (Table 4), while fruits from plants grafted onto $S$. aethiopicum gr. gilo (accession 2) rootstocks had the lowest value.

Table 4. Rootstock effect on pulp lightness measured immediately after cutting $\left(\mathrm{L}_{0}\right)$ in the central and lateral area and the fruit browning $\left(\Delta \mathrm{L}_{30}\right)$ of the lateral area in 'Scarlatti' $\mathrm{F}_{1}$ scion.

\begin{tabular}{cccc}
\hline Treatments & $\mathbf{L}_{\mathbf{0}}$ Central Area & $\mathbf{L}_{\mathbf{0}}$ Lateral Area & $\mathbf{\Delta L}_{\mathbf{3 0}}$ Lateral Area \\
\hline Rootstock & & & \\
'Scarlatti' ungrafted & $82.4 \mathrm{bc}$ & $80.6 \mathrm{~b}$ & $2.5 \mathrm{bc}$ \\
S. torvum & $82.9 \mathrm{~b}$ & $81.0 \mathrm{~b}$ & $2.3 \mathrm{c}$ \\
'Scarlatti' self-grafted & $82.5 \mathrm{~b}$ & $80.6 \mathrm{~b}$ & $2.5 \mathrm{bc}$ \\
Hybrid S. melongena $\times$ & $83.5 \mathrm{ab}$ & $81.5 \mathrm{ab}$ & $2.7 \mathrm{ab}$ \\
S. aethiopicum & $84.8 \mathrm{a}$ & $82.9 \mathrm{a}$ & $2.7 \mathrm{ab}$ \\
S. aethiopicum (accession 1) & $80.7 \mathrm{c}$ & $78.9 \mathrm{c}$ & $2.9 \mathrm{a}$ \\
S. aethiopicum (accession2) & & & $* * * *$ \\
Significance & $* * *$ & $*$ & $*$
\end{tabular}

Values within a column and a year followed by the same letter are not significantly different at $p \leq 0.05$ (Tukey HSD Test). The significance is designated by asterisks as follows: ${ }^{*}$, statistically significant differences at $\mathrm{p}$-value below $0.05 ; * *$, statistically significant differences at $p$-value below $0.01 ; * * *$, statistically significant differences at $p$-value below 0.001 ; NS $=$ not significant.

Data collected for $\mathrm{L}_{0}$ lateral area supported the trend established for $\mathrm{L}_{0}$ central area (Table 4).

S. aethiopicum gr. gilo (accessions 1 and 2) and S. melongena $\times$ S. aethiopicum gr. gilo hybrid rootstocks induced the highest $\Delta \mathrm{L}_{30}$ lateral area values (Table 4). While, S. torvum rootstock induced the lowest one.

ANOVA for total anthocyanins was not statistically significant (Table 5).

Table 5. Rootstock effect on total antocyanins, glycoalkaloids, chlorogenic acid, and proteins in 'Scarlatti' $\mathrm{F}_{1}$ scion.

\begin{tabular}{|c|c|c|c|c|}
\hline Treatments & $\begin{array}{c}\text { Total } \\
\text { Anthocyanins } \\
\left(\mathrm{mg} \cdot 100 \mathrm{~g}^{-1} \text { of } \mathrm{fw}\right)\end{array}$ & $\begin{array}{l}\text { Glycoalkaloids } \\
\text { (mg-100 } \mathrm{g}^{-1} \text { of fw) }\end{array}$ & $\begin{array}{l}\text { Chlorogenic Acid } \\
\left(\mathrm{mg} \cdot 100 \mathrm{~g}^{-1} \text { of } \mathrm{fw}\right)\end{array}$ & $\begin{array}{l}\text { Proteins (g.100 } \\
\mathrm{g}^{-1} \text { of } \mathrm{fw} \text { ) }\end{array}$ \\
\hline \multicolumn{5}{|l|}{ Rootstock } \\
\hline 'Scarlatti' ungrafted & $60.6 \mathrm{~ns}$ & $8.4 \mathrm{a}$ & $21.7 \mathrm{ab}$ & $1.0 \mathrm{ab}$ \\
\hline S. torvum & $43.0 \mathrm{~ns}$ & $1.0 \mathrm{~b}$ & $40.3 \mathrm{a}$ & $1.0 \mathrm{ab}$ \\
\hline 'Scarlatti' self-grafted & $47.8 \mathrm{~ns}$ & $2.7 \mathrm{~b}$ & $34.1 \mathrm{a}$ & $1.0 \mathrm{ab}$ \\
\hline $\begin{array}{l}\text { Hybrid S. melongena } \times \\
\text { S. aethiopicum }\end{array}$ & $70.8 \mathrm{~ns}$ & $8.6 \mathrm{a}$ & $4.4 \mathrm{~b}$ & $0.9 \mathrm{bc}$ \\
\hline S. aethiopicum (accession 1) & $80.0 \mathrm{~ns}$ & $3.7 \mathrm{~b}$ & $40.0 \mathrm{a}$ & $1.1 \mathrm{ab}$ \\
\hline S. aethiopicum (accession 2) & $106.4 \mathrm{~ns}$ & $1.9 \mathrm{~b}$ & $17.9 \mathrm{ab}$ & $0.8 \mathrm{~d}$ \\
\hline \multicolumn{5}{|l|}{ Significance } \\
\hline Rootstock & NS & * & $* *$ & $* * *$ \\
\hline
\end{tabular}

Values within a column and a year followed by the same letter are not significantly different at $p \leq 0.05$ (Tukey HSD Test). The significance is designated by asterisks as follows: *, statistically significant differences at $p$-value below $0.05 ; * *$, statistically significant differences at $p$-value below $0.01 ; * * *$, statistically significant differences at $p$-value below 0.001; NS = not significant; $\mathrm{fw}=$ fresh weight.

The highest glycoalkaloids content was observed in fruits from ungrafted plants and in those from plants grafted onto S. melongena $\times$ S. aethiopicum gr. gilo rootstocks (Table 5).

Fruits from 'Scarlatti' grafted on S. torvum, S. aethiopicum gr. gilo (accession 1), and 'Scarlatti' self-grafted plants had the highest chlorogenic acid content, whereas, fruits from plants grafted onto $S$. melongena $\times$ S. aethiopicum gr. gilo hybrid rootstock showed the lowest value (Table 5). 
We found that protein content in fruits from plants grafted onto S. aethiopicum gr. gilo (accession 1) was slightly higher than those from 'Scarlatti' ungrafted, self-grafted, and S. torvum grafted plants. The lowest protein content was detected in fruits from plants grafted onto S. aethiopicum gr. gilo (accession 2) (Table 5).

Rootstock significantly affected mineral content (Figure 1).

Ungrafted, self-grafted, and S. torvum rootstock grafted plants had the highest fruit P content (538, 551 , and $541 \mathrm{mg} \cdot 100 \mathrm{~g}^{-1}$ of $\mathrm{dw}$, respectively). The lowest fruit P content value ( $395.4 \mathrm{mg} \cdot 100 \mathrm{~g}^{-1}$ of $\mathrm{dw}$ ) was found in S.melongena $\times$ S. aethiopicum gr. gilo hybrid rootstock (Figure 1). Fruits harvested from plants grafted on S. aethiopicum gr. gilo (accession 1) rootstock had a significantly lower K content $\left(302.9 \mathrm{mg} \cdot 100 \mathrm{~g}^{-1}\right.$ of $\mathrm{dw}$ ) in comparison to those grafted onto 'Scarlatti', S. torvum, S. melongena $\times$ S. aethiopicum gr. gilo hybrid, S. aethiopicum gr. gilo (accession 2), and 'Scarlatti ungrafted (341.0, 349.0, $341.3,359.1$, and $354.4 \mathrm{mg} \cdot 100 \mathrm{~g}^{-1}$ of $\mathrm{dw}$, respectively) (Figure 1). Moreover, no significant differences were found among plants grafted onto 'Scarlatti', S. torvum, S. melongena $\times$ S. aethiopicum gr. gilo hybrid, S. aethiopicum gr. gilo (accession 2), and 'Scarlatti ungrafted for fruit K content. 'Scarlatti' grafted onto S. melongena $\times$ S. aethiopicum gr. gilo hybrid gave the highest fruit Ca content $\left(108.9 \mathrm{mg} \cdot 100 \mathrm{~g}^{-1} \mathrm{of} \mathrm{dw}\right)$, whereas fruits from plants grafted S. aethiopicum gr. gilo (accession 2) gave the lowest $\mathrm{Ca}$ fruit content (99.4 mg. $100 \mathrm{~g}^{-1}$ of dw) (Figure 1). 'Scarlatti' grafted onto S. aethiopicum gr. gilo (accessions 1 and 2) and S. melongena $\times$ S. aethiopicum gr. gilo hybrid had the highest $\mathrm{Mg}$ content $(19.3,18.1$, and $18.6 \mathrm{mg} 100$ $\mathrm{g}^{-1}$ of $\mathrm{dw}$, respectively) (Figure 1), whereas the lowest $\mathrm{Mg}$ contents were found in fruits from 'Scarlatti' grafted on S. torvum (13.8 mg.100 $\mathrm{g}^{-1}$ of $\left.\mathrm{dw}\right)$.

\section{Discussion}

Nowadays, both a high yield performance and fruit quality attributes (intrinsic and extrinsic) are very important due to the functional role of vegetables in the human diet [29].

Along with approaches such as genetic improvement and optimization of the cultivation conditions, herbaceous grafting technique represents a toolbox for securing or increasing yield stability and fruit quality with or without stress conditions [26,34-37]. In this paper, we investigated the effects of $S$. aethiopicum gr. gilo (accessions 1 and 2) versus the interspecific hybrid of S. melongena $\times$ S. aethiopicum gr. gilo on plant performance and fruit quality attributes of 'Scarlatti' eggplant $\mathrm{F}_{1}$ hybrid (black cylindrical shape). All the results are compared with those obtained from non-grafted, self-grafted, and S. torvum rootstock grafted plants.

Grafting success is an important concern when using new scion-rootstock combinations [37]. Generally, Solanaceous crops are grafted by cleft or tube grafting methods $[4,20,38]$. In our experiment using the tube grafting technique, grafting success rates of $89.1 \%$ for S. aethiopicum gr. gilo (accession 1 ), 93.6\% for S. aethiopicum gr. gilo (accession 2), and over 99\% for grafting onto 'Scarlatti', S. torvum, and S. melongena $\times$ S. aethiopicum gr. gilo hybrid, were observed. Our findings are in accord with those obtained by Bletsos et al. [4] and Rahman et al. [39], who reported a high grafting success rate of eggplant cultivars grafted onto $S$. torvum. Although, Solanum aethiopicum gr. gilo is a close relative species of S. melongena [16], from our results it appears that graft incompatibility might exist especially when 'Scarlatti' is grafted onto S. aethiopicum gr. gilo accession 2. Thus, we may assume that the genotype is a crucial aspect for the identification of a suitable rootstock as significant differences may exist between different accessions of a species. Regarding the S. melongena $\times$ S. aethiopicum gr. gilo hybrid rootstock, our outcomes are in accord with those obtained by Gisbert et al. [9], who reported a high graft success rate when interspecific hybrids of eggplants were used as rootstocks. Our results are also consistent with those of Sabatino et al. [10], who reported a high graft success rate of eggplant 'Birgah' $F_{1}$ hybrid (violet globose shape) grafted onto S. melongena $\times$ S. aethiopicum rootstock, confirming the capacity of this interspecific hybrid to give good results with two different types of common eggplant. In fact, Birgah is one of the violet $\mathrm{F}_{1}$ hybrid belonging to a local Sicilian fruit typology that has been subjected to lower breeding improvement efforts when compared to elongated black-purple typelike 'Scarlatti', which is world-wide diffused especially in the most industrialized countries. Our experiment confirms 
that rootstock might play a major role on plant biometric parameters. Plant height, which may be considered an indicator of vigor was highest in plants with S. aethiopicum gr. gilo (accession 1), S. torvum, and interspecific hybrid S. melongena $\times$ S. aethiopicum gr. gilo rootstocks and lowest in those plants with S. aethiopicum gr. gilo (accession 2) rootstock grafts. Therefore, vigor of the rootstock is important in conferring scion vigor. In the absence of grafting incompatibility signals, grafted plants may also develop more rapidly, hence contributing to earliness. In our work, plants grafted onto S. torvum and S. melongena $\times$ S. aethiopicum gr. gilo hybrid rootstocks flowered earlier than those grafted on the other rootstocks tested. Our results are consistent with those obtained by Gisbert et al. [9] and Sabatino et al. [10], who reported that plant vigor is positively related to fruit earliness. Increased earliness has also been reported for other fruiting vegetables such as melon grafted onto Cucurbita rootstock [40,41]. In our experiment, grafting has proved a useful technique to enhance eggplant 'Scarlatti' $\mathrm{F}_{1}$ hybrid yield traits. We also found that plants grafted onto S. melongena $\times$ S. aethiopicum gr. gilo hybrid rootstock had higher total and marketable yield plant ${ }^{-1}$ than plants grafted onto S. aethiopicum gr. gilo (accessions 1 and 2), confirming that this latter rootstock has little value for enhancing eggplant yield. Conversely, interspecific hybrid of S. melongena $\times$ S. aethiopicum gr. gilo rootstock demonstrated great improvements in agronomic performance due to grafting. However, in our study grafting did not increase the number of marketable fruits. These findings are different from those of Gisbert et al. [9] and Sabatino et al. [10], who reported that eggplants grafted onto interspecific hybrids produced consistently more fruits per plant than ungrafted ones. However, despite in the present work grafting did not significantly improve the number of fruits per plant, the data recorded in our experiment supported the trend established in the experiments by Gisbert et al. [9] and Sabatino et al. [10]. On the other hand, these findings seem to be consistent with those obtained by Maršič et al. [42], who reported that, in the second trial, grafting did not increase the number of fruit per plant in eggplant 'Galine' $F_{1}$ (eggplant cylindrical shape). Therefore, it seems that the number of fruit per plant is a yield component influenced by the genetic background of the rootstock scion combination.

Apparent visual quality is an important criterion when consumers decide to purchase eggplant fruits. In our study, rootstocks affect fruit length and fruit calyx length. Our results are in accord with those obtained by Gisbert et al. [9], who hypothesized that fruit shape changes are probably due to changes in the concentration of growth regulators induced by the rootstock. Our findings on apparent visual quality are partially different from those of Sabatino et al. [10], who reported that rootstock significantly influences fruit width but has no significant effect on calyx length. Thus, it seems that, although fruit shape in eggplant is highly heritable and under genetic control $[43,44]$ and even though rootstocks may affect cultivar fruit shape parameters due to changes in the concentration of growth regulators [9], rootstock may differently affect specific fruit shape characters in relation to the scion genotype.

Our results demonstrated that rootstock may enhance $\mathrm{H}^{\circ}$ color parameter of skin eggplant fruit. Our outcomes are in contrast with those of Moncada et al. [45], who revealed that $S$. torvum rootstock decreased $\mathrm{H}^{\circ}$ parameter in 'Black Bell', 'Black Moon', and 'Longo' eggplants. Thus, it seems that fruit skin color parameters are differently affected by scion-rootstock combination. Moreover, in our study, fruits from plants grafted onto S. torvum and S. melongena $\times$ S. aethiopicum gr. gilo hybrid had the highest $\mathrm{H}^{\circ}$ color parameter value, which is an important commercial and qualitative prerequisite in eggplant fruit. Eggplant ranks among the top 10 vegetables in terms of antioxidant fruit activity. Accordingly to these data, a high fruit pulp browning potential could be expected [46,47]. Mishra et al. [46], King et al. [48], and Prohens et al. [49] revealed that eggplant cultivars differed in their extents of post-cut browning, which could be due to variations in the PPO activity or level of soluble phenolics. Our results on pulp browning are consistent with the findings of Sabatino et al. [10], who reported little or no effect of grafting by using S. torvum rootstock. However, we also found that fruits from plant grafted onto S. aethiopicum gr. gilo (accessions 1 and 2) revealed the highest value in terms of $\Delta \mathrm{L}_{30}$. 
Mennella et al. [19] revealed that chlorogenic acid is the major monomeric phenolic compound in eggplant fruits. Although few differences were found in fruit composition traits, higher fruit chlorogenic acid content was found in fruits harvested from plants with 'Scarlatti', S. torvum, S. aethiopicum gr. gilo (accessions 1 and 2) rootstocks, and ungrafted plants in comparison to fruits harvested from 'Scarlatti' scions grafted onto S. melongena $\times$ S. aethiopicum gr. gilo hybrid. This higher chlorogenic acid concentration may be an additional indication of stress in this rootstock-scion combination, as stress conditions induce accumulation of phenolics [50,51]. Our results are dissimilar from those of Sabatino et al. [10], who reported no differences in terms of fruit chlorogenic acid content among rootstocks tested, but are consistent with those of Sabatino et al. [26] who reported that grafting significantly increased phenolic concentration in fruits from grafted eggplant landraces only in three out of four genotypes. Our outcomes on phenolic content are also consistent with those of Maršič et al. [42] who demonstrated that grafting significantly increased phenolic concentration in fruits from a grafted eggplant landrace as opposed to commercial varieties. Moreover, Toppino et al. [52] discovered environment-specific QTLs associated to the amount of chlorogenic acid. Accordingly, it seems that fruit phenolic content in eggplant is a quality trait also affected by scion-rootstock interactions. Mennella et al. [19], Friedman and McDonald [53], and Friedman [54] observed that genetic, environment, and growing conditions may affect glycoalkaloids concentration in potato, tomato, and eggplant. In addition, Jones and Fenwick [55] and Krits et al. [56] assessed that the level of total glycoalkaloids in potato tubers should not exceed $200 \mathrm{mg} \cdot \mathrm{kg}^{-1}$ of fw (or $200 \mathrm{mg} \cdot 100 \mathrm{~g}^{-1} \mathrm{of} \mathrm{dw}$ ). Glycoalkaloids concentration ranged from 0.98 to $8.64 \mathrm{mg} \cdot 100 \mathrm{~g}^{-1}$ of fresh weight. Rootstock affected glycoalkaloids concentration in eggplant; however, it is important to remark that glycoalkaloids amount in fruits from grafted plant remained below the recommended threshold value. Our findings are in contrast with those of Sabatino et al. [10], who observed no significant differences in terms of glycoalkaloids concentration in 'Birgah' $F_{1}$ eggplant fruits from plants grafted onto several potential rootstocks including hybrids and allied species.

Generally, changes in overall fruit composition between grafted and ungrafted plants were reported in tomato [57] and pepper [58]. Our results are in accord with those of Sabatino et al. [10], who found some differences in fruit quality attributes among fruits from ungrafted or self-grafted plants.

\section{Conclusions}

After the ban of methyl bromide use for soil fumigation, the soilborne diseases arising from continuous cropping are major issues that negatively affect productivity in eggplant. In this scenario, grafting is an effective tool to control vegetable crop stresses. Nowadays, S. torvum and tomato hybrids are the main eggplant rootstocks commercially used. However, investigations on the influence of new rootstocks on biometric parameters, yield performance, and fruit quality characteristics of different eggplant groups can provide further advances in this specific grafting field. In the present study, the interspecific hybrid of $S$. melongena $\times$ S. aethiopicum gr. gilo exhibited high grafting compatibility and high yield performance. These findings, together with the absence of negative effects on apparent 'Scarlatti' $F_{1}$ hybrid fruit quality and composition, demonstrate that this interspecific hybrid may be a viable rootstock alternative to $S$. torvum.

Supplementary Materials: The following are available online at http://www.mdpi.com/2073-4395/9/5/223/s1, Figure S1: Monthly meteorological data from May to August of 2014 and 2015 from the meteorological station of the experimental farm of the Department of Agricultural, Alimentary and Forest Sciences, University of Palermo, Italy, Figure S2: Plant height evolution of 'Scarlatti' eggplant plant ungrafted, self-grafted and grafted onto S. torvum, S. aethiopicum gr. gilo (accession 1), S. aethiopicum gr. gilo (accession 2) and S. melongena $\times$ S. aethiopicum gr. gilo rootstocks. Bars indicate the standard error of the mean. ANOVA analysis for plant height at 50, 80, and 110 DAT showed the following significance: *** (statistically significant differences at $p$-value below $0.001),{ }^{* * *}$ and * (statistically significant differences at $p$-value below 0.05), respectively, Figure S3: Root collar evolution of 'Scarlatti' eggplant plant ungrafted, self-grafted and grafted onto S. torvum, S. aethiopicum gr. gilo (accession 1), S. aethiopicum gr. gilo (accession 2) and S. melongena $\times$ S. aethiopicum gr. gilo rootstocks. Bars indicate the standard error of the mean. ANOVA analysis for root collar at 50, 80, and 110 DAT showed the 
following significance: ${ }^{* * *}$ (statistically significant differences at $p$-value below 0.001$),{ }^{* *}$ and ${ }^{* * *}$, respectively. Table S1: Rootstock effects on apparent fruit quality in 'Scarlatti' F1 scion.

Author Contributions: L.S., G.I., G.L.R., and F.D., conceived and designed the research. L.S. also carried out field work, analyzed the data, and wrote the manuscript. E.P. and G.M. performed laboratory analytical determination. G.I. and G.L.R. helped draft the manuscript. All authors read and approved the manuscript.

Funding: This research received no external funding.

Acknowledgments: We thank Carlo Prinzivalli for his assistance in establishing the field trial.

Conflicts of Interest: The authors declare no conflict of interest.

\section{References}

1. FAOSTAT. Production. Available online: www.fao.org (accessed on 16 January 2019).

2. Kaushik, P.; Prohens, J.; Vilanova, S.; Gramazio, P.; Plazas, M. Phenotyping of eggplant wild relatives and interspecific hybrids with conventional and phenomics descriptors provides insight for their potential utilization in breeding. Front. Plant Sci. 2016, 7, 677. [CrossRef]

3. D'Anna, F.; Sabatino, L. Morphological and agronomical characterization of eggplant genetic resources from the Sicily area. J. Food Agri. Environ. 2013, 11, 401-404.

4. Bletsos, F.; Thanassoulopoulos, C.; Roupakias, D. Effect of grafting on growth, yield and Verticillium wilt of eggplant. HortScience 2003, 38, 183-186. [CrossRef]

5. Colla, G.; Rouphael, Y.; Jawad, R.; Kumar, P.; Rea, E.; Cardarelli, M. The effectiveness of grafting to improve $\mathrm{NaCl}$ and $\mathrm{CaCl}_{2}$ tolerance in cucumber. Sci. Hortic. 2013, 164, 380-391. [CrossRef]

6. Kumar, P.; Rouphael, Y.; Cardarelli, M.; Colla, G. Vegetable grafting as a tool to improve drought resistance and water use efficiency. Front. Plant Sci. 2017, 8, 1130. [CrossRef] [PubMed]

7. Kumar, P.; Lucini, L.; Rouphael, Y.; Cardarelli, M.; Kalunke, R.M.; Colla, G. Insight into the role of grafting and arbuscular mycorrhiza on cadmium stress tolerance in tomato. Front. Plant Sci. 2015, 6, 477. [CrossRef]

8. Ginoux, G.; Laterrot, H. Greffage de l'aubergine. Proceedings reflexions du portegreffe. PHM Revue Hortic. 1991, 321, 49-54.

9. Gisbert, C.; Prohens, J.; Raigón, M.D.; Stommel, J.R.; Nuez, F. Eggplant relatives as sources of variation for developing new rootstocks: Effects of grafting on eggplant yield and fruit apparent quality and composition. Sci. Hortic. 2011, 128, 14-22. [CrossRef]

10. Sabatino, L.; Iapichino, G.; D'Anna, F.; Palazzolo, E.; Mennella, G.; Rotino, G.L. Hybrids and allied species as potential rootstocks for eggplant: Effect of grafting on vigour, yield and overall fruit quality traits. Sci. Hortic. 2018, 228, 81-90. [CrossRef]

11. Kyriacou, M.C.; Rouphael, Y.; Colla, G.; Zrenner, R.; Schwarz, D. Vegetable grafting: The implications of a growing agronomic imperative for vegetable fruit quality and nutritive value. Front. Plant Sci. 2017, 8, 741. [CrossRef]

12. Cappelli, C.; Stravato, V.M.; Rotino, G.L.; Buonaurio, R. Sources of resistance among Solanum spp. to an Italian isolate of Fusarium oxysporum $\mathrm{f} \mathrm{sp}$. melongenae. In Proceedings of the 9th EUCARPIA Meeting Genetic and Breeding of Capsicum and Eggplant, Budapest, Hungary, 21-25 August 1995; pp. 221-224.

13. Rizza, F.; Mennella, G.; Collonnier, C.; Shiachakr, D.; Kashyap, V.; Rajam, M.V.; Prestera, M.; Rotino, G.L. Androgenic dihaploids from somatic hybrids between Solanum melongena and S. aethiopicum group gilo as a source of resistance to Fusarium oxysporum f. sp. melongenae. Plant Cell Rep. 2002, 20, 1022-1032.

14. Hébert, Y. Comparative resistance of nine species of the genes Solanum to bacterial wilt Psedomonas solanacearum and the nematode Meloidogyne incognita. Implications for the breeding of aubergine (S. melongena) in the humid tropical zone. Agronomie 1985, 5, 27-32. [CrossRef]

15. Prohens, J.; Plazas, M.; Raigón, M.D.; Seguí-Simarro, J.M.; Stommel, J.R.; Vilanova, S. Characterization of interspecific hybrids and backcross generations from crosses between two cultivated eggplants (Solanum melongena and S. aethiopicum Kumba group) and implications for eggplant breeding. Euphytica 2012, 186, 517-538. [CrossRef]

16. Sawadogo, B.; Bationo-Kando, P.; Sawadogo, N.; Kiebre, Z.; Kiebre, M.; Nanema, K.R.; Traore, R.E.; Sawadogo, M.; Zongo, J.D. Variation, correlation and heritability of interest characters for selection of African eggplant. Afr. Crop Sci. J. 2016, 24, 213-221. [CrossRef] 
17. Toppino, L.; Mennella, G.; Rizza, F.; D'alessandro, A.; Sihachakr, D.; Rotino, G.L. ISSR and isozyme characterization of androgenetic dihaploids reveals tetrasomic inheritance in tetraploid somatic hybrids between Solanum melongena and Solanum aethiopicum group gilo. J. Hered. 2008, 99, 304-315. [CrossRef] [PubMed]

18. Toppino, L.; Vale, G.; Rotino, G.L. Inheritance of fusarium wilt resistance introgressed from Solanum aethiopicum Gilo and Aculeatum groups into cultivated eggplant (S. melongena) and development of associated PCR-based markers. Mol. Breed. 2008, 22, 237-250. [CrossRef]

19. Mennella, G.; Rotino, G.L.; Fibiani, M.; D'Alessandro, A.; Francese, G.; Toppino, L.; Cavallanti, F.; Acciarri, N.; Lo Scalzo, R. Characterization of health-related compounds in eggplant (Solanum melongena L.) lines derived from introgression of allied species. J. Agric. Food Chem. 2010, 58, 7597-7603. [CrossRef]

20. Lee, J.M. Cultivation of grafted vegetables I: Current status, grafting methods and benefits. Hort. Sci. 1994, 29, 235-239. [CrossRef]

21. Miceli, A.; Sabatino, L.; Moncada, A.; Vetrano, F.; D’Anna, F. Nursery and field evaluation of eggplant grafted onto unrooted cuttings of Solanum torvum Sw. Sci. Hortic. 2014, 178, 203-210. [CrossRef]

22. Baixauli, C. Berenjena. In La horticultura espãnola; Nuez, F., Llácer, G., Eds.; Ediciones de Horticultura: Reus, Spain, 2001.

23. Prohens, J.; Blanca, J.M.; Nuez, F. Morphological and molecular variation in a collection of eggplant from a secondary center of diversity: Implications for conservation and breeding. J. Am. Soc. Hortic. Sci. 2005, 130, 54-63. [CrossRef]

24. Larrigaudiere, C.; Lentheric, I.; Vendrell, M. Relationship between enzymatic browning and internal disorders in controlled atmosphere stored pears. J. Sci. Food Agric. 1998, 78, 232-236. [CrossRef]

25. Concellòn, A.; Añón, M.; Chaves, A.R. Effect of low temperature storage on physical and physiological characteristics of eggplant fruit (Solanum melongena L.). LWT 2007, 40, 389-396. [CrossRef]

26. Sabatino, L.; Iapichino, G.; Maggio, A.; D’Anna, E.; Bruno, M.; D’Anna, F. Grafting affects yield and phenolic profile of Solanum melongena L. landraces. J. Integr. Agric. 2016, 15, 1017-1024. [CrossRef]

27. Fogg, D.N.; Wilkinson, N.T. The colorimetric determination of phosphorus. Analist 1958, 83, $406-414$. [CrossRef]

28. Morand, P.; Gullo, J.L. Mineralisation des tissus vegetaux en vue du dosage de P, Ca, Mg, Na, K. Ann. Agron. 1970, 21, 229-236.

29. Stommel, J.R.; Whitaker, B.D. Phenolic acid content and composition of eggplant fruit in a germplasm core subset. J. Am. Soc. Hortic. Sci. 2003, 128, 704-710. [CrossRef]

30. Mennella, G.; Lo Scalzo, R.; Fibiani, M.; D’Alessandro, A.; Francese, G.; Toppino, L.; Acciarri, N.; De Almeida, A.E.; Rotino, G.L. Chemical and bioactive quality traits during fruit ripening in eggplant (S. melongena L.) and allied species. J. Agric. Food Chem. 2012, 60, 11821-11831. [CrossRef]

31. Lo Scalzo, R.; Fibiani, M.; Mennella, G.; Rotino, G.L.; Dal Sasso, M.; Culici, M.; Spallino, A.; Braga, P.C. Thermal treatments of eggplant (Solanum melongena L.) increases the antioxidant content and the inhibitory effect on human neutrophil burst. J. Agric. Food Chem. 2010, 58, 3371-3379. [CrossRef]

32. Birner, J. A method for the determination of total steroid bases. J. Pharm. Sci. 1969, 58, 258-259. [CrossRef]

33. Kuronen, P.; Väänänen, T.; Pehu, E. Reversed-phase liquid chromatographic separation and simultaneous profiling of steroidal glycoalkaloids and their aglycones. J. Chromatogr. A. 1999, 863, 25-35. [CrossRef]

34. Sabatino, L.; Palazzolo, E.; D'Anna, F. Grafting suitability of Sicilian eggplant ecotypes onto Solanum torvum: Fruit composition, production and phenology. J. Food Agric. Environ. 2013, 11, 1195-1200.

35. Davis, A.R.; Perkins-Veazie, P.; Hassell, R.; Levi, A.; King, S.R.; Zhang, X.P. Grafting effects on vegetable quality. HortScience 2008, 43, 1670-1672. [CrossRef]

36. Rouphael, Y.; Kyriacou, M.; Colla, G. Vegetable grafting: A toolbox for securing yield stability under multiple stress conditions. Front. Plant Sci. 2018, 8, 2255. [CrossRef]

37. Kawaguchi, M.; Taji, A.; Backhouse, D.; Oda, M. Anatomy and physiology of graft incompatibility in solanaceous plants. J. Hortic. Sci. Biotechnol. 2008, 83, 581-588. [CrossRef]

38. Miguel, A.; de la Torre, F.; Baixauli, C.; Maroto, J.V.; Jordá, M.C.; López, M.M.; García- Jiménez, J. Elinjerto de hortalizas; Ministerio de Agricultura, Pesca y Alimentación: Madrid, Spain, 2007.

39. Rahman, M.A.; Rashid, M.A.; Hossain, M.M.; Salam, M.A.; Masum, A.S.M.H. Grafting compatibility of cultivated eggplant varieties with wild Solanum species. Pak. J. Biol. Sci. 2002, 5, 755-757. 
40. Cohen, R.; Horev, C.; Burger, Y.; Shriber, S.; Hershenhorn, J.; Katanand, J.; Edelstein, M. Horticultural and pathological aspects of Fusarium wilt management using grafted melons. Hort. Sci. 2002, 37, 1069-1073. [CrossRef]

41. Fita, A.; Picó, B.; Roig, C.; Nuez, F. Performance of Cucumis melo spp. agrestis as a rootstock for melon. J. Hortic. Sci. Biotechnol. 2004, 82, 184-190.

42. Maršič, N.K.; Mikulič-Petkovšek, M.; Štampar, F. Grafting influences phenolic profile and carpometric traits of fruits of greenhouse-grown eggplant (Solanum melongena L.). J. Agric. Food Chem. 2014, 62, 10504-10514. [CrossRef] [PubMed]

43. Muñoz-Falcón, J.E.; Prohens, J.; Rodríguez-Burruezo, A.; Nuez, F. Potential of local varieties and their hybrids for the improvement of eggplant production in the open field and greenhouse cultivation. J. Food Agric. Environ. 2008, 6, 83-88.

44. Portis, E.; Barchi, L.; Toppino, L.; Lanteri, S.; Acciarri, N.; Felicioni, N.; Fusari, F.; Barbierato, V.; Cericola, F.; Valè, G.; et al. QTL mapping in eggplant reveals clusters of yield-related loci and orthology with the tomato genome. PLoS ONE 2014, 9, e89499. [CrossRef] [PubMed]

45. Moncada, A.; Miceli, A.; Vetrano, F.; Mineo, V.; Planeta, D.; D'Anna, F. Effect of grafting on yield and quality of eggplant (Solanum melongena L.). Sci. Hortic. 2013, 149, 108-114. [CrossRef]

46. Mishra, B.B.; Gautam, S.; Sharma, A. Free phenolics and polyphenol oxidase (PPO): The factors affecting post-cut browning in eggplant (Solanum melongena). Food Chem. 2013, 139, 105-114. [CrossRef] [PubMed]

47. Singh, A.P.; Luthria, D.; Wilson, T.; Vorsa, N.; Singh, V.; Banuelos, G.S.; Pasakdee, S. Polyphenols content and antioxidant capacity of eggplant pulp. Food Chem. 2009, 114, 955-961. [CrossRef]

48. King, S.R.; Davis, A.R.; Zhang, X.; Crosby, K. Genetics, breeding and selection of rootstocks for Solanaceae and Cucurbitaceae. Sci. Hortic. 2010, 127, 106-111. [CrossRef]

49. Prohens, J.; Rodriguez-Burruezo, A.; Raigon, M.D.; Nuez, F. Total phenolic concentration and browning susceptibility in a collection of different varietal types and hybrids of eggplant: Implications for breeding for higher nutritional quality and reduced browning. J. Am. Soc. Hortic. Sci. 2007, 132, 1-9. [CrossRef]

50. Dixon, R.A.; Paiva, N.L. Stress-induced phenylpropanoid metabolism. Plant Cell 1995, 7, $1085-1097$. [CrossRef] [PubMed]

51. Moglia, A.; Lanteri, S.; Comino, C.; Acquadro, A.; de Vos, R.; Beekwilder, J. Stress induced biosynthesis of dicaffeoylquinic acids in globe artichoke. J. Agric. Food Chem. 2008, 56, 8641-8649. [CrossRef]

52. Toppino, L.; Barchi, L.; Lo Scalzo, R.; Palazzolo, E.; Francese, G.; Fibiani, M.; D'Alessandro, A.; Papa, V.; Laudicina, V.A.; Sabatino, L.; et al. Mapping quantitative trait loci affectingbiochemical and morphologicalfruitproperties in eggplant (Solanum melongena L.). Front. Plant Sci. 2016, 7, 256. [CrossRef]

53. Friedman, M.; McDonald, G.M. Potato glycoalkaloids: Chemistry, analyses, safety and plant physiology. Crit. Rev. Plant Sci. 1997, 16, 55-132. [CrossRef]

54. Friedman, M. Tomato glycoalkaloids: Role in the plant and in the diet. J. Agric. Food Chem. 2002, 50, 5751-5780. [CrossRef]

55. Jones, P.G.; Fenwick, G.R. The glycoalkaloid content of some edible solanaceous fruits and potato products. J. Sci. Food Agric. 2006, 32, 419-421. [CrossRef]

56. Krits, P.; Fogelman, E.; Ginzberg, I. Potato steroidal glycoalkaloid levels and the expression of key isoprenoid metabolic genes. Planta 2007, 227, 143-150. [CrossRef]

57. Khah, E.M.; Kakava, E.M.A.; Chachalis, D.; Goulas, C. Effect of grafting on growth and yield of tomato (Lycopersicon esculentum Mill.) in greenhouse and open field. J. Appl. Hortic. 2006, 8, 3-7.

58. Gisbert, C.; Sánchez-Torres, P.; Raigón, M.D.; Nuez, F. Phytophthora capsici resistance evaluation in pepper hybrids: Agronomic performance and fruit quality of pepper grafted plants. J. Food Agric. Environ. 2010, 8 , 116-121.

(C) 2019 by the authors. Licensee MDPI, Basel, Switzerland. This article is an open access article distributed under the terms and conditions of the Creative Commons Attribution (CC BY) license (http://creativecommons.org/licenses/by/4.0/). 